\title{
Teaching Culture through Reading Literature in English Language Teaching
}

\begin{abstract}
English as a lingua franca (ELF) has become a standardized mode of communication between diverse sociocultural groups. Besides linguistic competence, English language learners should possess adequate intercultural competence to establish successful social relations worldwide. Therefore, one of the main objectives of English language teaching (ELT) has become the development of intercultural speakers (Byram 1997; Kramsch 1998). One way of achieving this is by using literature in the classroom because learners interpret literary texts from their personal experience and are thus engaged both at a cognitive and an emotional level. Their individual interpretations can nevertheless also lead to generalizations and enforcement of stereotypes about foreign cultures. Hanauer (2001) has developed a method called focuson-cultural understanding to expose learners to different interpretations. The study explores whether his method can be successfully applied in the context of Croatian university education. The method has proven to be effective for raising learners' cultural awareness, which could lead to further development of their intercultural competence.
\end{abstract}

Keywords: literature, cultural awareness, intercultural competence, English language teaching (ELT), English as a lingua franca (ELF)

\section{Poučevanje kulture z branjem književnosti pri pouku angleškega jezika}

\author{
IZVLEČEK
}

Angleščina kot lingua franca (ELF) je postala standardiziran način komunikacije med različnimi sociokulturnimi skupinami. Poleg jezikovne kompetence bi morali imeti učenci angleščine ustrezne medkulturne kompetence za vzpostavitev uspešnih družbenih odnosov po vsem svetu. Zato je eden glavnih ciljev poučevanja angleškega jezika razvoj medkulturnih govorcev (Byram 1997; Kramsch 1998). Eden od načinov za dosego tega je uporaba literature v razredu, saj učenci interpretirajo literarna besedila iz svojih osebnih izkušenj, kar vključuje tako kognitivno kot čustveno raven. Njihove individualne interpretacije lahko vodijo tudi v posploševanje in uveljavljanje stereotipov o tujih kulturah. Hanauer (2001) je razvil metodo, imenovano »osredotočenost na kulturno razumevanje«, ki učence izpostavila različnim interpretacijam. V študiji raziskujemo, ali je mogoče njegovo metodo uspešno uporabiti v kontekstu hrvaškega univerzitetnega izobraževanja. Metoda se je izkazala za učinkovito pri dvigovanju kulturne ozaveščenosti učencev, kar bi lahko vodilo $\mathrm{k}$ nadaljnjemu razvoju njihove medkulturne kompetence.

Ključne besede: književnost, kulturna ozaveščenost, medkulturna kompetenca, poučevanje angleškega jezika, angleščina kot lingua franca 


\section{Introduction}

Since the process of globalization has contributed to the increased mobility of population, the objectives of English language teaching (ELT) at all its levels should be focused on the specific needs of twenty-first century learners who are likely to communicate in various sociocultural settings. The development of linguistic competence alone is no longer sufficient to suit the needs of global citizens, and the development of intercultural speakers (Byram 1997; Kramsch 1998) has become a priority in ELT. A lack of intercultural competence may lead to cultural misunderstandings, often hindering successful communication, so that it is crucial that intercultural competence is embedded within the English language curriculum (Brown 2000).

In ELT, teachers should use culturally relevant materials to raise learners' cultural awareness and foster their intercultural understanding. To this end, literary texts are suitable for ELT because they frequently deal with complex cultural issues. However, they are subject to individual interpretations. To prevent the formation of generalizations and stereotypes, Hanauer (2001) developed the focus-on-cultural understanding method for the teaching of culture through the reading of literature. He argues that learners should be exposed to "multiple individual viewpoints" $(2001,396)$ in order to become sensitive towards the cultural norms and expectations which are valued in different communities. The aim of the present study is to explore the effectiveness of Hanauer's method in the context of Croatian university education with third-year undergraduate students double-majoring in English at the University of Zadar. Despite several limitations to the study, such as the students' age, gender and similar sociocultural background, we expect Hanauer's method to be effective for raising the learners' cultural awareness, fostering the development of empathy and understanding of otherness.

The paper is structured as follows: Section 2 gives a brief overview of the importance of cultural education within ELT. Section 3 outlines the benefits of using literary texts for the development of learners' intercultural competence. Section 4 details the analysis and discussion, which lead to the conclusion in section 5 .

\section{Language and Culture}

In today's society, English as a lingua franca (ELF) is used beyond national boundaries as a means of communication between groups speaking different languages. As a result, English has more international users than native speakers (Faber 2010), and its use prevails not only in numerous fields but also in everyday communication. Deficiencies in communicative and taskbased approaches have come to the foreground, so that the creation of near native speakers is no longer the most important outcome of ELT. Since cultural misunderstandings often hinder successful communication and prevent the creation of successful social relationships, there has been a need for an intercultural approach in ELT because it is the "central objective of language learning to promote the favourable development of the learner's whole personality and sense of identity in response to the enriching experience of otherness in language and culture" (Council of Europe 2001, 1). In other words, if learners' intercultural skills are developed together with their communicative skills, they will be equipped for successful communication in various multilingual and multicultural contexts. Teachers should thus endeavour to raise their 
students' cultural awareness within the English language curriculum. As culture gives meaning and context to language, it is impossible to teach one without the other (Brown 2000). When learning a foreign language, learners encounter a new culture and compare it to their native culture becoming aware of the similarities and differences between the cultures and express their positive or negative attitudes towards them (Byram 1989; Kramsch 2000; Liddicoat 2004). They become actively involved in the creation of their knowledge about the culture, and this can lead to the development of their cultural awareness (Liddicoat 2004; Liddicoat et al. 2003). Discussing cultural diversity broadens learners' horizons and prepares them to understand and accept other cultures, so that they can become more sensitive to others.

This is particularly important when it comes to ELT, because ELF is used in international communication between members of different linguistic and cultural communities. Not only is it spoken in the cultural context of the target language, but also in other cultural contexts, whereby at least three cultures are involved in communication (Kramsch 1991; Willems 1996). In fact, ELF does not belong to individual nations or cultures but to all those cultures worldwide where it plays a significant role. In formal education, ELT seems to be responsible for intercultural learning because different cultures should be taught within its framework (Bland 2018). To illustrate, the source culture, i.e., the learners' native culture, should find its place in the English language classroom because it is beneficial for the development of a positive cultural identity. Only if students learn how to appreciate their own cultural values, will they be able to understand and accept those of others. The inclusion of the target culture in the English language curriculum acts as a motivational force for learning the language, while simultaneously developing positive attitudes towards the foreign culture. Due to the specific nature of the English language, it is of utmost importance to incorporate international culture within the curriculum in order to address its use among various cultures and its place in global society (Cortazzi and Jin 1999; Matsuda 2012). On the whole, integrating different cultures in ELT will foster the development of learners' intercultural competence, an important tool for successful communication in diverse intercultural contexts.

\section{Using Literature in ELT}

English language teachers often face challenges in this respect as textbooks may lack relevant cultural information, but there are various authentic materials which can be used in the classroom as well. Authentic materials are written by native speakers in order to communicate ideas, and they can be interpreted within the cultural context in which they are created (Morrow 1977). Since literary texts frequently deal with various cultural issues, they can serve as a widely available primary source for the English language classroom. When learners are asked to interpret literary works, they not only interpret them within the particular cultural context, but also interact with them in relation to their own experiences, thus becoming engaged both emotionally and creatively. This contributes to their cultural understanding and the development of their intercultural competence (Kramsch 2000).

Bland (2018) argues that literature provides readers with access to foreign cultures and languages, offering a new perspective in the globalized world. If English language teachers use both literary texts dealing with learners' native culture and those dealing with foreign 
cultures in their classroom, they will encourage their students to discuss cultural issues from different perspectives, which will foster intercultural understanding and empathy for others. Therefore, teachers should endeavour to choose literary texts which include various experiences from around the world with equal access to diverse perspectives, because "books are sometimes the only place where readers may meet people who are not like themselves, who offer alternative worldviews" (Tschida, Ryan, and Ticknor 2014, 29). This calls for the need to include multicultural literature in the English language classroom alongside British or American literature (Pulverness 2004). Teachers should select literary texts that are not only written by native speakers, but also by authors using ELF, ensuring a holistic approach to English literature.

Not only do literary texts develop learners' linguistic skills, but they also require interpretation skills and develop learners' cultural awareness. McRae $(1991,2008)$ claims that the language of literary texts is representational rather than referential, because it operates on more than one level, and is open to interpretation and requires negotiation to be understood. There is thus a need to include a fifth skill ${ }^{1}$ in ELT which involves language awareness, text awareness, and cultural awareness. This skill requires time and energy dedicated to learners forming opinions and subsequent discussions of individual ideas. Students should be motivated to interpret literary texts through different analytical tasks to understand the cultural issues represented in a particular literary work, and it is important that they give their individual contribution in the discussion, in which there are no incorrect answers and students are encouraged to express their opinions freely. By using creative tasks, for example, a role play or retelling the story from somebody else's perspective, students can experience different cultural issues through the characters. In this way they become aware of what is acceptable in a particular culture, which can raise their cultural awareness and develop their cultural understanding.

When interacting with a literary text, learners are involved both at a cognitive and an emotional level. Not only are they required to infer meanings, but they are also confronted with the subjective worlds of characters which they observe from different perspectives (Bredella 1996, 2000; Brumfit and Carter 2000; Burwitz-Meltzer 2001; Delanoy 1993; Kramsch 2000, 2003; Rogers and Soter 1997; Soter 1997). Learners are required to interpret foreign cultures from a point of view of their own and, in that way, they develop critical self-awareness, tolerance, and empathy for otherness (Phipps and González, 2004; Zacharias $2005)$. Hall $(2005,80)$ states that "a classroom informed by ideas of discourse and dialogue encourages and explores and values alternative perspectives and experiences". Through the discussion about various cultural issues, learners become aware of cultural norms. They come to understand values different from their own and learn to accept "the others' beliefs and values, even if [...] [they] cannot approve of them” (Bredella 2003, 594).

Learners do not interpret literary texts in the same way as native speakers because they interpret them with a different sociocultural background and from their own personal experience. According to Kramsch (2000), these are the differences between "cultural reality" and "cultural imagination", and the teachers' task is "to ensure that the synthesis that is born

Besides the four linguistic skills, i.e., listening, speaking, reading, and writing. 
from this encounter will occur in a third space" (Gonçalves Matos 2005, 60). The term "third space" refers to the space between the two cultures. It is the space where learners integrate their own understanding and expectations with a literary text, and become involved in the meaning making process. In this process, they might misinterpret some of the conversations due to the conventions which are inaccessible to them and, as a result, the literary text might be misunderstood. The role of the teacher is to clarify the points that cause misunderstanding (Brumfit and Carter 2000) because "literature per se does not necessarily provide a master key for understanding a foreign culture" (Delanoy 1993, 278).

Since literary texts are subject to individual interpretations and not representative of a whole society, they can reinforce prejudices and stereotypes, and it is one of the central issues in cultural education to avoid these generalizations (Edmondson 1997; Hall 2005). Hanauer $(2001,395)$ claims that "[...] literary texts are not self-explanatory [...] [but] tend to be ambiguous and polysemous [...] [and] are open to a multiplicity of meaning construction options". The interpretation of literary texts depends on "the designs of meaning making" which are part of the culture $(2001,396)$, and language teachers can show their learners the ways in which different individuals and communities might understand these texts. As cultures are composed of individuals who have different cultural relationships and are members of different ethnic, religious and ideological groups, there are multiple sets of cultural meanings within any country, so that the teaching of culture should include the presentation of "multiple individual viewpoints" (2001, 396). Even though a literary work presents the author's personal presentation of life and values, it can be interpreted in different culturally specific ways by the members of the same community, and this can help learners understand the complexities of the target culture.

Therefore, Hanauer $(2001,401)$ developed a theoretically based method for the teaching of culture through the reading of literature named focus-on-cultural understanding. It is based on the theory of multiliteracy according to which "every culture develops its own set of designs of meaning making [...] [which] are socially embedded and historically constituted" (Cope and Kalantzis 2000, 9). The cultural context serves as a framework for meaning construction, whereby the culture of a particular community is defined by the various designs of meaning making produced by the members of that community. In other words, while learning a foreign culture, students learn the community's ways of constructing and producing meaning which can be different from the values and meanings of their own cultures. The central aspect of Hanauer's method is "the presentation and discussion of multiple interpretations of the literary work by members of the target culture and comparison of these to the understandings of language learner" (Hanauer 2001, 403). Even though literary interpretations are believed to limit students' personal interpretations in first language learning pedagogy (Britton 1968), experts' interpretations can help students understand how individual meanings are produced within the target culture. These experts are native speakers from the target culture whose interpretations can contribute to learners' different understandings of a literary text.

Besides native speakers' interpretations, the students' culturally specific view of the target culture should be included and compared with other culturally specific ways of constructing meaning. This includes a confrontation of the interpretations of the same literary text by 
learners and members of the target language community, whereby language learners can compare the different ways in which meaning is constructed both by them and by native speakers. As this task focuses on the meaning making process, it is called the task of focuson-cultural understanding. In the classroom, learners' understandings of the literary text are brought in juxtaposition to native speakers' understandings of the text. Through comparison, learners can understand the culturally specific meaning making processes, i.e., the ways in which members of the target culture construct meaning.

The learning environment should support multiple interpretations in relation to the difference between understandings of distant and close cultural groups. This means that the teacher should respect students' interpretations of the literary text because native speakers' interpretations should only help learners develop discussions over the differences in meaning making. It is also important that the teacher chooses "culturally embedded texts" (2001, 401) in order to provoke discussion of culturally specific meanings. Literary texts which are considered controversial within the target culture will show all its complexities instead of presenting it in an idealized manner, and "the language teacher needs to focus on those aspects of the task which involve culturally specific meaning construction" (Hanauer 2001, 402), so that learners can understand the target culture with all its complexities.

\section{Analysis and Discussion}

\subsection{Methodology}

The present study was designed to test the effectiveness of Hanauer's method ${ }^{2}$ for the development of students' cultural awareness in relation to the issue of racial discrimination in the context of Croatian university education, and it addressed the following research questions:

RQ1. a) What is the participants' perception of different foreign cultures, i.e., Australian and Indian, as well as their native culture, i.e., Croatian?

b) Does the participants' perception of different foreign cultures, i.e., Australian and Indian as well as their native culture, i.e., Croatian, change after the activities?

RQ2. a) What are the participants' attitudes towards the two foreign cultures as well as towards their native culture?

b) Do the activities influence the participants' attitudes towards the two foreign cultures as well as towards their native culture?

\footnotetext{
A similar study was conducted in Poland in 2012 by Wąsikiewicz-Firlej. In her paper "Developing Cultural Awareness through Reading Literary Texts", she investigated the effectiveness of Hanauer's method in the context of the Polish higher education setting. In her study she focused on the perception of the gender identity and gender roles in the USA, Japan and Poland. The research questions in the present study are based upon the research questions that Wąsikiewicz-Firlej used in her study; however, this study focuses on the issue of racial discrimination.

3 In research questions $1 \mathrm{a}, 1 \mathrm{~b}, 2 \mathrm{a}$, and $2 \mathrm{~b}$ we wanted to make a distinction between the terms perception and attitude because, according to Oxford Learner's Dictionary, perception is "an idea, a belief or an image you have as a result of how you see or understand something" (2021b), whereas attitude is "the way you think and feel about somebody/ something or the way you behave towards somebody or something that shows how you think and feel” (2021a). In
} 
RQ3. a) Are the participants motivated for cultural education?

b) Do the activities influence the participants motivation for cultural education?

RQ4. What is the participants' attitude towards the effectiveness of this method?

RQ5. Do the participants think that intercultural education should be part of ELT?

The research was conducted in May 2019 at the University of Zadar in Croatia within the compulsory course Contemporary English Language VI on a sample of 57 (48 female and nine male) third-year undergraduate Croatian students (level C1/C2) aged between 21 and 23, double-majoring in English. At the time of the study, they had been learning English between 12 and 16 years, and 53 students had been abroad before the time of the research. Eight students consider themselves bilingual, whereas 49 students claim to be multilingual, speaking German (30 students), Spanish (18 students), Italian (17 students), Russian (14 students), and French (13 students) besides Croatian and English.

Before doing the activities, the students were given a questionnaire containing personal questions as well as reasons for studying English. According to their answers, their reasons for studying English are mainly communication (53 students), work (53 students), travel (35 students), and getting to know other cultures (23 students). A few students listed other reasons for studying English such as understanding popular cultures (one student), working in tourism (one student), media and entertainment (one student), and "an easy choice after high school" (one student).

The literary text chosen for the research was the short story A Really Splendid Evening written by the Australian author Lesley Rowlands, which was originally published in a magazine in 1963 and reprinted in Best Australian Short Stories (1975, eds. Stewart and Davis). This story was chosen for its recognized importance within the target culture. Since it deals with racial discrimination, we expected it to provoke discussion on this sensitive topic. The short story shows the representatives of the target culture, i.e., Australians, confronting another culture, i.e., Indian. It illustrates a culture clash and the protagonist's experience of culture shock when he comes to visit the Australian couple whom he hardly knows. The story features Rao, a young Indian technician, who visits the home of the wealthy Australian couple, Mary and Harry Greenberg, upon Mr Greenberg's invitation, which is portrayed as insincere. This could be considered a debatable element of culture related to different attitudes towards accepting people's invitations in both cultures. The story describes what happens on that "really splendid evening". In order to collect the data, we used the pre-questionnaire, the students' interpretations of the short story, the native speakers' interpretations of the short story, the students' discussion, and the post-questionnaire. We assumed that the reading of the short story and the accompanying activities with the focus on the discussion about the complexities of each one of these cultures would have an impact on the participants' perception of the three cultures as well as their attitudes towards the members from these cultures. We believed that the aforementioned activities would have an impact on their motivation for cultural education within ELT.

other words, perception is the first stage of human reaction to any external impulse and leads to building our attitude, i.e., to forming our behaviour and actions. 


\subsection{The Pre-questionnaire}

In the first stage of the research, before reading the short story, the students were provided with the pre-questionnaire, which was conducted using a Likert scale from 1-5 in which 1 stands for "strongly disagree" and 5 for "strongly agree" (1 - strongly disagree; 2 - disagree; 3 - neither agree nor disagree; 4 - agree; 5 - strongly agree). It contained 12 statements (Appendix 1) in order to check the participants' perceptions of Australian, Indian, and Croatian culture, their attitudes towards them, as well as their motivation for cultural education. Our aim was to collect the data related to the students' general perceptions of the different cultures represented in the short story, i.e., Australian and Indian, and their own culture, i.e., Croatian, as well as their attitudes towards the members of these cultures. Using Statements 1-8, we wanted to examine whether the students were likely to express discrimination towards any of these three cultures without addressing the complexities of each of them. Statements 9-11 served as an introduction to the method used in the research which provides an instrument for the development of cultural awareness in the ELT classroom. We wanted our participants to reflect upon reading literature as a potential means of fostering cultural understanding which, according to Hanauer (2001), could be achieved through the meaning making process. Statement 12 was aimed at provoking the students' self-reflection in relation to their motivation for learning about other cultures.

TABLE 1 . The results of the pre-questionnaire.

\begin{tabular}{|c|l|c|}
\hline No. & Statement & Mean \\
\hline 1 & People in Australia are tolerant towards other nations. & 3.65 \\
\hline 2 & People in India are tolerant towards other nations. & 2.98 \\
\hline 3 & People in Croatia are tolerant towards other nations. & 3.00 \\
\hline 4 & Discrimination exists in all cultures. & 4.63 \\
\hline 5 & Discrimination is more evident in some cultures than in others. & 4.51 \\
\hline 7 & My attitude towards Australian culture is positive. & 4.46 \\
\hline 8 & My attitude towards Indian culture is positive. & 3.56 \\
\hline 9 & My attitude towards Croatian culture is positive. & 3.96 \\
\hline 10 & $\begin{array}{l}\text { It is difficult to understand foreign cultural values (people's } \\
\text { attitudes, behaviour, feelings, beliefs). }\end{array}$ & 3.05 \\
\hline 11 & $\begin{array}{l}\text { Reading literature leads to the development of empathy and } \\
\text { sensitivity towards foreign cultures. }\end{array}$ & 4.14 \\
\hline 12 & Iown stereotypes. & 4.65 \\
\hline
\end{tabular}

Table 1 shows the participants' evaluations of the statements. When it comes to the participants' perceptions of different foreign cultures, i.e., Australian and Indian, as well as their native culture, i.e., Croatian (Statements 1-5), it is evident that the most of them perceive Australians 
as more tolerant $($ mean=3.65) than Croatians (mean=3.00), while Indians are perceived as the least tolerant (mean=2.98). The reason for this might be that Croatian learners are not very familiar with Indian culture; on the other hand, they learn about Anglophone cultures within the English language curriculum in formal education in Croatia. The majority of students think that discrimination exists in all countries (mean=4.63), but is more evident in some than in others (mean=4.51). The participants generally have positive attitudes towards these cultures (Statements 6-9), particularly towards Australian culture (mean=4.46). They believe that it is difficult to understand foreign cultural values (mean=3.05). When asked about their motivation for cultural education (Statements 10-12), it is obvious that they are very motivated to learn about other cultures (mean=4.67) and think that it broadens their horizons and breaks down stereotypes (mean=4.65). They find reading literature useful for raising cultural awareness $($ mean=4.14). This indicates that the students are aware of the complexity of being able to understand cultural differences and, at the same time, of the necessity and motivation for learning about them and developing their intercultural skills by reading literature.

\subsection{Students' Interpretations of the Short Story}

After the pre-questionnaire, the students were asked to read the short story and answer the following questions:

1. What is the attitude of the Australian couple towards the Indian? Find examples in the story that support your opinion.

2. What are the reasons for their behaviour?

3. Do you think similar things happen in today's society in Australia?

4. Do similar things happen in Croatia? Give examples.

Even though in the pre-questionnaire the students expressed their positive attitudes towards Australian culture, after reading the short story they described the Australian couple as disrespectful, ignorant, disapproving, and judgemental. The participants believe that the Australians in the short story are full of stereotypes and prejudices and feel superior due to their different sociocultural background. The Greenbergs' condescending attitude towards Rao, the Indian, is in some cases interpreted as racism (28 students), or as the consequence of the Greenbergs' higher social status (17 students), whereas only one student claims that there is no specific reason for this. Twenty students believe that the couple's feeling of superiority stems from their lack of knowledge and understanding of Indian culture, as well as their ignorance and unwillingness to learn about other cultures.

Excerpt 1. They are full of various prejudices towards Indians and their behaviour; they think that the Indians are rude, bad-mannered, uneducated and that it is hard for them to blend in a white society (racism). (Student 26)

Excerpt 2. There is a general clash between their racist sentiments and their sociallyconditioned urge to maintain their image of class and politeness. (Student 41)

Excerpt 3. They pretend they understand his culture, and they are snobs. (Student 36) 
Excerpt 4. They show disrespect towards the Indian and are not interested in getting to know his culture, and not understanding other cultures leads to building stereotypes and prejudice. (Student 56)

The majority of participants ( 55 students) think that racial discrimination is still present in Australia regardless of the fact that it is a multicultural country. It is especially directed towards Aborigines, as well as immigrants from different parts of the world, and is more common in rural areas and among older generations. The participants find that racial discrimination exists in Australia because the mixture of diverse multicultural groups with their own traditions and social norms could hinder intercultural understanding rather than foster it. Twenty-two students claim that racial discrimination happens not only in Australia but also all around the world. Nevertheless, 18 students think that the change is likely to come with younger generations who are more open-minded and likely to accept other cultures with all their complexities.

Excerpt 5. It would be unrealistic to think that it does not happen there since Australia is one of the most multicultural countries in the world - not everyone can be familiar with so many different cultures and understand other peoples' traditions, behaviours and social norms. It happens where different cultures collide. (Student 36)

Excerpt 6. Even though Australia is a multicultural country and more liberal than others, discrimination will always be present. (Student 10)

Excerpt 7. Today things have greatly improved because people in Australia and in general are more open to other cultures. (Student 30)

When it comes to their native culture, only two out of 57 students rejected the idea of any form of discrimination in Croatia. It seems that there are many stereotypes and prejudices in Croatia which are based on race, origin, religion, or sexual orientation. Nineteen students believe that such behaviour is caused by nationalism or false patriotism, mostly due to the fact that Croatia was at war in the 1990s, and its consequences are still felt throughout the country. That might be the reason why some Croatians feel superior towards people from neighbouring countries. According to 15 participants, Croatians show discrimination towards immigrants from the Middle East because Croatia has been a transit country during the recent immigration crisis. Six participants claim that there is evidence of racist behaviour towards people with different skin colour in Croatia, such as Chinese, Africans, or Japanese.

Excerpt 8. Racism is not prominent, it is more directed towards neighbouring cultures, there are toxic relationships between ex-Yu nationalities due to the still relatively recent war. (Student 41)

Excerpt 9. Unfortunately, [the] recent immigrant crisis has influenced the creation of Facebook groups warning people which places to avoid because they were seen there. (Student 44)

Excerpt 10. Croatia is a small country with little diversities, Catholic and white, so there are a lot of stereotypes, even though it is a tourist destination. They call all Asians Chinese, pointing out at somebody who is not white. (Student 55) 
Excerpt 11. A lady from Nigeria opened a restaurant in Zagreb and there were some negative reactions. (Student 57)

Discrimination also happens inside the country due to the differences between dialects, customs, and beliefs. Throughout the past, parts of Croatia were under the rule of foreign powers, such as Italy and the Austro-Hungarian Empire, which influenced the dialects, traditions, customs, and behaviours of the people living in those areas.

Excerpt 12. In Croatia there is discrimination not only towards other cultures but inside the country itself - people from Zagorje or Slavonia are not always accepted - I wasn't accepted well because of my accent/language, sometimes I was even laughed at. (Student 50)

Sixteen participants think that discrimination is present in Croatia among older generations who are not willing to learn about foreign cultures. On the other hand, young people are more open-minded because nowadays they travel for different reasons and should be able to form successful social relationships in different sociocultural contexts.

Excerpt 13. Most people are narrow-minded and superficial because they have never travelled abroad and learned about new cultures. (Student 16)

Excerpt 14. It is connected with older generations, who have no will to open their minds to new cultures and different people. (Student 3 )

Excerpt 15. Young people are more open-minded, because they are more interested in learning about other cultures, and with every new generation people are learning more and becoming more welcoming. (Student 28)

There are 22 students who find racial discrimination a global issue which should be addressed beyond national boundaries.

Excerpt 16. In theory they are trying to reduce it, but in practice it will take a long time to change any kind of discrimination (nationalism, racism); it is happening all around the world. (Student 1)

The students believe that cultural knowledge is easily accessible nowadays, so that people should learn about other cultures in order be more tolerant and ready to accept others and otherness because the fear of the unknown is caused by a lack of knowledge and narrowmindedness.

\subsection{Native Speakers' Interpretations}

Six Australian native speakers of English (four female and two male, aged between 25 and 60) wrote their interpretations of the short story and delivered them by email. They answered the same questions as the students, excluding question 4. The students were asked to read the native speakers' interpretations of the short story and to compare them with their own interpretations working in groups of five or six students and focusing on the similarities and differences between their viewpoints. In the discussion, they were required to make a list of the key points which they would present to the whole class following the group work activity. During the open-class discussion, the teacher pointed out that, even though the native 
speakers' interpretations provided authentic experiences of the people from the target culture, they should be regarded only as personal, individual viewpoints. The aim of the discussion was to provoke the students' interest in different views and to make a clear distinction between their perceptions and attitudes based on their previous experiences prior to and after being exposed to the instruments used in the research. The students were highly motivated to participate in the discussion in which they supported their opinions with their personal experience.

The native speakers described the Australians in the short story as disinterested, embarrassed about the presence of the Indian, condescending, indifferent, impatient, insincere, and disrespectful. According to the native speakers, the Australian couple show racial prejudice towards the Indian because they are snobs and feel superior. They do not show any interest in trying to understand his culture, which is different to their own. The Australian native speakers of English included in the study also think that discrimination still exists in their country.

Excerpt 17. Racial and cultural prejudice still occurs in Australian society today as people from different cultures still do not accept or care to learn/discover new cultures. Australian society can be quite sheltered and people can go their whole lives living in this bubble. (Native speaker 1)

Excerpt 18. Possibly so; but not only confined to Australia. Australia is a multicultural society but there are still people who would unfortunately still have some of these values. (Native speaker 2)

Excerpt 19. Naturally yes in a country with so many different cultures, there will be many that might not understand foreigners' customs. Australians have gained many amazing things from being so multicultural including cuisines and customs, and these cultures make up the Australian population and are what make it a special country. It's important for Australians to remember this and being open to others. (Native speaker 3)

However, one opinion differs significantly from the others. Native speaker 5 describes the couple's misbehaviour from a different social aspect claiming that, in this short story, racism is irrelevant in comparison to the class discrimination in its influence on the Greenbergs' attitude towards their Indian guest. They belong to a higher social class than Rao and feel embarrassed when they are seen in his company. The situation would have been different if the Indian had been their equal. This opinion was brought up in the open-class discussion as relevant, because it expressed an interesting point regarding the cultural issues discussed in relation to this short story. Since the short story was written in the 1960s, the native speaker as well as some students believe that both class and racial discrimination influenced the Greenbergs' attitude towards Rao.

Excerpt 20. While this story probably represents a typical attitude for the time in which it is set, or written, it's not so common today, as this is more a reflection of European (British) class discrimination, segregation, imported into Australian society until the 1950s. While racial discrimination in Australia at this time was also highly prevalent, it's not demonstrated by the Greenbergs' behaviour in this particular story, e.g., Ms Greenberg would have enjoyed the company of an Indian, if he had been a "prince". (Native speaker 5)

Excerpt 21. Being rich turned them into snobs (probably would be the same if he wasn't 
an Indian but just a member of the lower class society). (Student 29)

Excerpt 22. They belong to an upper class of society - probably they would behave the same if he was an Australian from a lower class. (Student 17)

It is evident that the native speakers find their culture discriminatory, but they believe that it has changed to some extent among younger generations. The majority identified racism as the key reason for the Australian couple's behaviour towards the Indian. Both the students and the native speakers showed similar perceptions of the target culture. Since the students were presented with multiple individual viewpoints, they were involved in the meaning making process being exposed to the complexities of different cultures. In that way, they are included in the process of intercultural education which is beneficial for the development of their intercultural competence.

\subsection{The Post-questionnaire (Part 1)}

After the activities connected to the short story, the students were asked to complete the postquestionnaire (Appendix 2) using the Likert scale. The first part of the post-questionnaire (Statements 1-12) contained the same statements as the pre-questionnaire so that we could check whether the activities influenced the participants' perceptions of different cultures, their attitudes towards them, as well as their motivation for cultural education.

TABLE 2. The comparison of the results of the pre-questionnaire and the post-questionnaire (Part 1).

\begin{tabular}{|c|l|c|c|c|}
\hline No. & Statement & Preq. & Postq. & Difference \\
\hline 1 & $\begin{array}{l}\text { People in Australia are tolerant towards other } \\
\text { nations. }\end{array}$ & 3.65 & 3.47 & -0.18 \\
\hline 2 & $\begin{array}{l}\text { People in India are tolerant towards other } \\
\text { nations. }\end{array}$ & 2.98 & 3.42 & +0.44 \\
\hline 3 & $\begin{array}{l}\text { People in Croatia are tolerant towards other } \\
\text { nations. }\end{array}$ & 3.00 & 2.96 & -0.04 \\
\hline 4 & Discrimination exists in all cultures. & 4.63 & 4.77 & +0.14 \\
\hline 5 & $\begin{array}{l}\text { Discrimination is more evident in some cultures } \\
\text { than in others. }\end{array}$ & 4.51 & 4.54 & -0.03 \\
\hline 6 & My attitude towards Australian culture is positive. & 4.46 & 4.04 & -0.42 \\
\hline 7 & My attitude towards Indian culture is positive. & 3.56 & 3.65 & +0.09 \\
\hline 8 & My attitude towards Croatian culture is positive. & 3.96 & 3.91 & -0.05 \\
\hline 9 & $\begin{array}{l}\text { It is difficult to understand foreign cultural values } \\
\text { people's attitudes, behaviour, feelings, beliefs). }\end{array}$ & 3.05 & 3.19 & +0.14 \\
\hline 10 & $\begin{array}{l}\text { Reading literature leads to the development of } \\
\text { empathy and sensitivity towards foreign cultures. }\end{array}$ & 4.14 & 4.33 & +0.19 \\
\hline 11 & $\begin{array}{l}\text { Learning about foreign cultures broadens your } \\
\text { horizons and breaks down stereotypes. }\end{array}$ & 4.65 & 4.68 & +0.03 \\
\hline 12 & I want to find out more about other cultures. & 4.65 & 4.58 & -0.09 \\
\hline
\end{tabular}


Table 2 shows the comparison of the results of the pre-questionnaire and the post-questionnaire (Part 1, Statements 1-12). After the activities, the students rated Australians (-0.18) and Croatians $(-0.04)$ as less tolerant, but Indians as more tolerant $(+0.44)$ (Statements 1-3). It can be assumed that the previous activities raised the participants' cultural awareness regarding Indian culture with which they had not been particularly familiar. The results might also have been affected by the students' empathy developing while reading the short story. After the reading activities, more students $(+0.14)$ stated that discrimination exists in all countries, and fewer students $(-0.03)$ that it is more evident in some countries than in others (Statements 4-5). The participants' attitudes towards all cultures changed after the activities (Statements 6-8). Fewer students have a positive attitude towards Australian culture $(-0.42)$ and Croatian culture $(-0.05)$, whereas more students $(+0.09)$ expressed a positive attitude towards Indian culture. While reading and discussing the short story, they were able to identify with the character representing Indian culture and had an opportunity to show their sensitivity to the injustice that was done to him. There are more students $(+0.14)$ who believe that it is difficult to understand foreign cultural values. As regards their motivation for cultural education (Statements 9-12), more students $(+0.19)$ find reading literature useful for raising cultural awareness. More students $(+0.03)$ think that reading literature broadens their horizons and breaks down stereotypes. However, it is surprising that fewer students $(-0.09)$ now feel motivated to learn about other cultures. This can be attributed to the fact that it is challenging to understand foreign cultural values, which can be discouraging for the students. According to 22 participants, cultural issues are not related to a specific culture but go beyond national boundaries, so that they should be discussed at the global level.

\subsection{The Post-questionnaire (Part 2)}

The second part of the post-questionnaire (Appendix 2, Part 2, Statements 13-20) contained eight further statements so as to check the influence of the activities on the development of the students' cultural awareness and motivation for cultural education.

Table 3 shows the results of the post-questionnaire (Part 2). According to the participants' answers, it can be argued that the majority find these activities helpful for raising their cultural awareness and are motivated to learn about different cultures, including non-Anglophone ones. Due to the specific needs of English language learners, language proficiency is no longer the sole prerequisite for their successful communication in various sociocultural settings. Only if they become competent intercultural speakers will they be equipped for living in the globalized world. While reading the short story, the students were confronted with the Australian couple representing Australian culture as discriminatory and racist. Having read the native speakers' interpretations of the short story, they were exposed to multiple individual viewpoints which helped them understand the complexities of the target culture, since the couples' behaviour could be attributed to some other factors typical of that cultural setting. It can be argued that this has proven the effectiveness of Hanauer's method in terms of understanding foreign cultures. The participants seem to have become aware of the fact that Australia is a multicultural country full of diversity, which can lead to various cultural issues that should not be simplified but looked upon from different perspectives. However, a smaller number of students (2.56) concluded that reading the short story helped them understand their own cultures. 
TABLE 3. The results of the post-questionnaire (Part 2).

\begin{tabular}{|c|l|c|}
\hline No. & Statement & Mean \\
\hline 13 & $\begin{array}{l}\text { Reading the short story has helped me understand elements of } \\
\text { different cultures. }\end{array}$ & 3.56 \\
\hline 14 & $\begin{array}{l}\text { Reading native speakers' interpretations of the short story has helped } \\
\text { me understand Australian culture. }\end{array}$ & 3.93 \\
\hline 15 & $\begin{array}{l}\text { Reading the short story has helped me gain a deeper insight into } \\
\text { various elements of foreign cultures. }\end{array}$ & 3.65 \\
\hline 16 & Reading the short story has helped me understand my own culture. & 2.56 \\
\hline 17 & $\begin{array}{l}\text { The activity has made me aware that the perception of racism is a } \\
\text { matter of culture. }\end{array}$ & 3.66 \\
\hline 18 & $\begin{array}{l}\text { Reading native speakers' interpretations has helped me reflect on my } \\
\text { own attitude towards race issues. }\end{array}$ & 3.53 \\
\hline 19 & $\begin{array}{l}\text { Reading the short story has raised my interest in learning about } \\
\text { different cultures. }\end{array}$ & 3.66 \\
\hline 20 & $\begin{array}{l}\text { Learning about other non-Anglophone cultures should be included in } \\
\text { this course. }\end{array}$ & 3.86 \\
\hline
\end{tabular}

\section{Conclusion}

The aim of this paper was to investigate the effectiveness of Hanauer's method with third-year undergraduate students of English at the University of Zadar in Croatia. The data were collected using different instruments in order to explore the participants' perceptions of Australian, Indian and Croatian cultures, their attitudes towards them and their motivation for cultural education before and after reading and interpreting the short story A Really Splendid Evening. The study also addressed the participants' attitudes towards the effectiveness of this method and towards cultural education in ELT in general. However, there were several limitations to the study. Since the participants are mostly female native speakers of Croatian coming from a similar sociocultural background, it can be assumed that these factors influenced their attitudes towards the cultural issues upon which the present study focused. As advanced university students of English, our participants are highly motivated to learn about other cultures because they are aware of the importance of the English language in intercultural communication. In order to collect more objective data, further research should also be conducted at the lower levels of ELT using suitable teaching materials, such as picture books and adapted literary texts. In our research, the students read only one short story, which may have limited their perception of different cultures, which calls for a need to include different culturally embedded literary texts in further research.

Even though the results of the pre-questionnaire are only slightly different from those of the post-questionnaire, the discussion that was part of our research shows that Hanauer's method seems to have been efficient in making our participants aware of the importance of understanding cultural differences and of the necessity of learning about them. While reading a literary text, the learners identify with the characters and experience other cultural 
perspectives. Through comparison of the characters' life experiences with their own, they make connections between the cultures and recognise and appreciate important values shared by different cultures. They become aware of other perspectives than their own and develop empathy and tolerance towards others and otherness (Hibbs 2016; Lütge 2013). When they are exposed to different interpretations of the literary text, they perceive different cultural issues through multiple viewpoints, which is likely to raise their cultural awareness and develop their cultural understanding. A supportive learning environment in which individual viewpoints are discussed and respected can help learners understand the complexities of different cultures that should not be idealized.

It is important that literature finds its place in the English language classroom, because literary texts frequently deal with various cultural issues which can be discussed within the English language curriculum. What is more, learners should read and interpret not only literary texts written by Anglophone authors, but also those written by authors who come from diverse sociocultural backgrounds and use ELF in intercultural communication. In that way, they will be exposed to a range of foreign cultures, which is of utmost importance because English has significantly more international users than native speakers. Only if English language learners develop their intercultural competence together with their language competence will they be equipped for successful communication in the globalized world. Therefore, English language teachers should develop their own intercultural competence and become intercultural mediators in order to raise their learners' sensitivity and interest in foreign cultures. Since a lack of knowledge about foreign cultures can lead to cultural misunderstanding, the process of intercultural education should start at the lowest levels of English language learning and be developed gradually throughout all its stages as an important component in the creation of global citizens.

\section{References}

Bland, Janice. 2018. "Introduction: The Challenge of Literature." In Using Literature in English Language Education: Challenging Reading for 8-18 Year Olds, edited by Janice Bland, 1-22. London: Bloomsbury Academic.

Bredella, Lothar. 1996. "The Anthropological and Pedagogical Significance of Aesthetic Reading in the

Foreign Language Classroom." In Challenges of Literary Texts in the Foreign Language Classroom, edited by Lothar Bredella and Werner Delanoy, 1-29. Tübingen: Gunter Narr.

—. 2000. "Literary Texts and Intercultural Understanding." In Routledge Encyclopedia of Language Teaching and Learning, edited by Michael Byram, 382-86. London: Routledge.

—. 2003. "Afterword: What does It Mean to Be Intercultural?" In Intercultural Experience and Education, edited by Geof Alred, Michael Byram, and Mike Fleming, 225-39. Clevedon: Multilingual Matters.

Britton, James N. 1968. "Response to Literature." In Response to Literature, edited by James R. Squire,

3-10. Champaign: National Council of Teachers of English.

Brown, H. Douglas. 2000. Principles of Language Learning and Teaching. New York: Longman.

Brumfit, Christopher, and Ron Carter. 2000. Literature and Language Teaching. Oxford: Oxford University Press.

Burwitz-Meltzer, Eva. 2001. “Teaching Intercultural Communicative Competence through Literature.” In Developing Intercultural Competence in Practice, edited by Michael Byram, Adam Nichols, and David Stevens, 29-43. Clevedon: Multilingual Matters.

Byram, Michael. 1989. Cultural Studies in Foreign Language Education. Clevedon: Multilingual Matters. 
—. 1997. “'Cultural Awareness' as Vocabulary Learning. ” Language Learning Journal 16: 51-57. https:// doi.org/10.1080/09571739785200291.

Cope, Bill, and Mary Kalantzis, eds. 2000. Multiliteracies: Literacy Learning and the Design of Social Futures. London: Routledge.

Cortazzi, Martin, and Lixian Jin. 1999. "Cultural Mirrors: Materials and Methods in the EFL Classroom." In Culture in Second Language Teaching, edited by Eli Hinkel, 196-219. Cambridge: Cambridge University Press.

Council of Europe. 2001. The Common European Framework of Reference for Languages: Learning, Teaching, Assessment. Cambridge: Cambridge University Press.

Delanoy, Werner. 1993. “'Come to Mecca': Assessing a Literary Text's Potential for Intercultural Learning.” In Experiencing a Foreign Culture, edited by Werner Delanoy, Johann Köberl, and Heinz Tschachler, 275-302. Tübingen: Gunther Narr.

Edmondson, William. 1997. "The Role of Literature in Foreign Language Learning and Teaching: Some Valid Assumptions and Invalid Arguments." AILA Review 12: 42-55.

Faber, Pamela. 2010. "English as an Academic Lingua Franca." Revista Alicantina de Estudios Ingleses 23: 19-32. https://doi.org/10.14198/raei.2010.23.02.

Gonçalves Matos, Ana. 2005. "Literary Texts: A Passage to Intercultural Reading in Foreign Language Education." Language and Intercultural Communication 5 (1): 57-71. https://doi.org/10.1080 $/ 14708470508668883$.

Hall, Geoff. 2005. Literature in Language Education. UK: Palgrave Macmillan.

Hanauer, David. 2001. "Focus-on-Cultural Understanding: Literary Reading in The Second Language Classroom." CAUCE, Revista de Filologia y su Didactica 24: 389-404. https:// cvc.cervantes.es/literatura/cauce/pdf/cauce24/ cauce24_23.pdf.

Hibbs, Brian. 2016. "Developing Students' Intercultural Competence through Children's and Adolescent Literature." Studie z aplikované lingvistiky-Studies in Applied Linguistic 7 (2): 7-19. https:// dspace.cuni.cz/bitstream/handle/20.500.11956/96457/1487078_brian_hibbs_7-19.pdf?sequence=1.

Kramsch, Claire. 1991. "Culture in Language Learning: A View from the United States." In Foreign Language Research in Cross-Cultural Perspective, edited by Kees de Bot, Claire Kramsch, and Ralph B. Ginsberg, 217-40. Amsterdam: John Benjamins.

—. 1998. "The Privilege of the Intercultural Speaker." In Language Learning in Intercultural Perspective, edited by Michael Byram and Mike Fleming, 16-31. Cambridge: Cambridge University Press.

-. 2000. Context and Culture in Language Teaching. Oxford: Oxford University Press.

- 2003. "From Practice to Theory and Back Again." In Context and Culture in Language Teaching and Learning, edited by Michael Byram, and Peter Grundy, 4-17. Clevedon: Multilingual Matters.

Liddicoat, Anthony J. 2004. “Intercultural Language Teaching: Principles for Practice.” New Zealand Language Teacher 30: 17-24.

Liddicoat, Anthony J., Leo Papademetre, Angela Scarino, and Michelle Kohler. 2003. Intercultural Language Learning. Canberra: DEST.

Lütge, Christiane. 2013. “Otherness in Children's Literature: Perspectives from the EFL Classroom.” In Children's Literature in Second Language Education, edited by Janice Bland, and Christiane Lütge, 97-105. London: Bloomsbury.

Matsuda, Aya. 2012. “Teaching Materials in EIL.” In Principles and Practices for Teaching English as an International Language, edited by Lubna Alsagoff, Sandra Lee McKay, Guangwei Hu, and Willy A. Renandya, 168-85. New York: Taylor \& Francis.

McRae, John. 1991. Literature with a Small "l". London and Basingstoke: Macmillan.

—. 2008. "What is Language and What Is Literature? Are They the Same Question? An Introduction to Literature with a Small 'l' and Five Skills English." FLuL-Fremdsprachen Lehren und Lernen 37: 63-80.

Morrow, Keith. 1977. "Authentic Texts and ESP." In English for Specific Purposes, edited by Susan Holden, 13-17. London: Modern English Publications. 
Oxford Learner's Dictionaries. 2021a. s.v. "attitude.” https://www.oxfordlearnersdictionaries.com/definition /english/attitude?q=attitude.

—. 2021b. s.v. "perception." https://www.oxfordlearnersdictionaries.com/definition/english/perception?q= perception.

Phipps, Alison, and Mike Gonzalez. 2004. Modern Languages: Learning and Teaching in an Intercultural Field. London: Sage.

Pulverness, Alan. 2004. "Here and There: Issues in Materials Development for Intercultural Learning." Paper given at the Culture ELT Seminar, organised by the British Council at Kraków 23-25 January, 2004.

Rogers, Theresa, and Anna Soter. 1997. Reading Across Cultures: Teaching Literature in a Diverse Society. Columbia University: Teachers College Press.

Soter, Anna. 1997. "Reading Literatures of Other Cultures: Some Issues in Critical Interpretation." In Reading across Cultures: Teaching Literature in a Diverse Society, edited by Theresa Rogers, and Anna Soter, 213-27. Columbia University: Teachers College Press.

Tschida, Christina M., Caitlin Ryan, and Anne Ticknor. 2014. "Building on Windows and Mirrors: Encouraging the Disruption of Single Stories through Children's Literature.” Journal of Children's Literature 40: 28-39.

Wąsikiewicz-Firlej, Emilia. 2012. "Developing Cultural Awareness through Reading Literary Texts." Taikomoji kalbotyra 1. https://doi.org/10.15388/TK.2012.17254.

Willems, Gerard M. 1996. "Foreign Language Study for Intercultural Communication." Multicultural Teaching 14 (3): 36-40.

Zacharias, Nugrahenny. 2005. "Developing Intercultural Competence through Literature." Celt 5 (1): 27-41. https://doi.org/10.24167/celt.v5i1.143.

\section{Appendix 1}

1. People in Australia are tolerant towards other nations.

2. People in India are tolerant towards other nations.

3. People in Croatia are tolerant towards other nations.

4. Discrimination exists in all cultures.

5. Discrimination is more evident in some cultures than in others.

6. My attitude towards Australian culture is positive.

7. My attitude towards Indian culture is positive.

8. My attitude towards Croatian culture is positive.

9. It is difficult to understand foreign cultural values (people's attitudes, behaviour, feelings, beliefs).

10. Reading literature leads to the development of empathy and sensitivity towards foreign cultures.

11. Learning about foreign cultures broadens your horizons and breaks down stereotypes.

12. I want to find out more about other cultures. 


\section{Appendix 2}

1. People in Australia are tolerant towards other nations.

2. People in India are tolerant towards other nations.

3. People in Croatia are tolerant towards other nations.

4. Discrimination exists in all cultures.

5. Discrimination is more evident in some cultures than in others.

6. My attitude towards Australian culture is positive.

7. My attitude towards Indian culture is positive.

8. My attitude towards Croatian culture is positive.

9. It is difficult to understand foreign cultural values (people's attitudes, behaviour, feelings, beliefs).

10. Reading literature leads to the development of empathy and sensitivity towards foreign cultures.

11. Learning about foreign cultures broadens your horizons and breaks down stereotypes.

12. I want to find out more about other cultures.

13. Reading the short story has helped me understand the elements of different cultures.

14. Reading native speakers' interpretations of the short story has helped me understand the Australian culture.

15. Reading the short story has helped me gain a deeper insight into various elements of foreign cultures.

16. Reading the short story has helped me understand my own culture.

17. The activity has made me aware that the perception of racism is a matter of culture.

18. Reading native speakers' interpretations has helped me reflect on my own attitude towards race issues.

19. Reading the short story has raised my interest in learning about different cultures.

20. Learning about other non-Anglophone cultures should be included in this course. 